\title{
CINEMATIC SPACE STUDIES OF KOMPLEK SUSTER- SUSTER ST. FRANSISKUS IN SEMARANG
}

\author{
${ }^{1}$ Nadira Anandisya, ${ }^{2}$ Caecilia S. Wijayaputri, ST., MT \\ ${ }^{1}$ Student in the Bachelor's (S-1) Study Program in Architecture \\ at Parahyangan Catholic University \\ 2 Senior lecturer in the Bachelor's (S-1) Study Program in Architecture \\ at Parahyangan Catholic University
}

\begin{abstract}
Cinema and Architecture are two art media that dependent on some human senses to give experience and define space compared of other art medium. These two media have been trying to show and convince film viewers or architecture users as a work of art. Both have quality value that will be higher if they can be as close to reality.

However, architecture tend to use visual but lack of emotions. As a result, buildings left us as only a viewers without invite us to engaged. Therefore, from cinema to architecture, the thinking of thematic conditions of architecture can be brought together with conceptual, contextual, architectonic, and technical.

Ave Maryam (2020) is a film that takes place in Semarang, and Kompleks Susteran St. Fransiskus is the main setting that interesting to studied. From each scene it can clearly describe space with a visual composition to convey a strong spatial experience. Departing from an approach to cinema that is parallel to architecture so that the audience can experience spaces outside the formal architectural experience.

The purpose of this study is to identify cinematic themes that can be discussed and reconstruct the cinematic space as a search for understanding the potential and meaning of cinematic in Kompleks Kesusteran St. Fransiskus based on the film Ave Maryam (2020). By using a qualitative descriptive method, from data that achieved by literature studies and film observations. It can be concluded that the existing approaches to architecture and cinema from Ave Maryam (2020) can be interpreted to build a concept that achieves the beauty and experience experienced in architecture such as watching the film.
\end{abstract}

Key Words: cinematic, architecture and film, cinematic approach, Ave Maryam, Komplek Kesusteran St. Fransiskus, Semarang.

\section{STUDI RUANG SINEMATIK KOMPLEK SUSTER-SUSTER ST. FRANSISKUS DI SEMARANG}

\author{
${ }^{1}$ Nadira Anandisya, ${ }^{2}$ Caecilia S. Wijayaputri, ST., MT \\ ${ }^{1}$ Mahasiswi S1 Program Studi Arsitektur Universitas Katolik Parahyangan \\ ${ }^{2}$ Dosen Pembimbing S1 Program Studi Arsitektur Universitas Katolik Parahyangan
}

\begin{abstract}
Abstrak - Sinema dan arsitektur adalah dua media seni yang bergantung pada beberapa indera manusia untuk memberikan pengalaman dan mendefinisi ruang dibandingkan medium lainnya. Kedua medium mencoba untuk menunjukan dan meyakinkan penonton film atau pengguna arsitektur yang menikmatinya sebagai karya seni bahwa nilai kualitas akan semakin tinggi jika karya tersebut semakin mendekati realita secara fisik.

Namun arsitektur menggunakan visual tapi cenderung kurang memiliki nuansa yang memiliki emosi. Sehingga, bangunan meninggalkan kita sebagai penonton tanpa menarik untuk membuat orang ikut berpartisipasi secara emosional. Dari sinema untuk arsitektur dapat dipertemukan pemikiran kondisi tematik arsitektur dengan distudi secara konseptual, kontekstual, arsitektonis, dan teknis.
\end{abstract}

\footnotetext{
${ }^{1}$ Corresponding Author: 42161515@student.unpar.ac.id
} 
Film Ave Maryam (2020) merupakan film yang mengambil lokasi syuting di Kota Semarang, dan Kompleks Susteran St. Fransiskus menjadi setting utama yang menarik untuk di studi. Dari tiap adegannya dapat memaparkan ruang dengan jelas dan komposisi visual untuk menyampaikan pengalaman ruang yang kuat. Berangkat dari pendekatan pada sinema yang paralel dengan arsitektur sehingga penonton pun dapat mengalami ruang diluar pengalaman arsitektur yang formal.

Tujuan studi ini adalah untuk mengidentifikasi tema sinematik yang dapat dibahas dan merekonstruksi ruang sinematik tersebut sebagai pencarian pemahaman potensi dan makna sinematik pada Kompleks Susteran St. Fransiskus berdasarkan film Ave Maryam (2020). Dengan menggunakan metode deskriptif kualitatif, dari data yang didapatkan dengan studi literatur dan observasi film. Diperoleh kesimpulan bahwa pendekatanpendekatan yang ada pada arsitektur dan sinema pada film Ave Maryam dapat diinterpretasikan untuk membangun konsep yang mencapai keindahan dan pengalaman yang dialami pada arsitektur seperti saat menonton film tersebut.

Kata Kunci: sinematik, arsitektur dan film, pendekatan sinematik, Film Ave Maryam, Komplek Kesusteran St. Fransiskus, Semarang

\section{PENDAHULUAN}

Arsitektur dan film merupakan medium yang paling terdekat dalam membahas ruang, aktivitas, dan waktu dibandingkan medium seni lainnya. Medium arsitektur atau film pun memberikan definisi pada ruang, seperti halnya bangunan dan kota yang menunjukan gambaran kebudayaan dan kehidupan tertentu, dan sinema yang menunjukan aspek kultural yang ada pada era yang digambarkan. Sehingga film cocok untuk menjadi media yang menggambarkan ruang arsitektur.

Film Ave Maryam merupakan film yang berceritakan mengenai kisah cinta seorang suster dan room di Kompleks Kesusteran St.Fransiskus, Semarang. Cinta yang merupakan bahasa universal yang dapat dipahami oleh berbagai pengalaman digambarkan juga pada setting utama. Ruang yang dipaparkan terkomposisi secara visual untuk memberikan pengalaman ruang pada penonton dapat dibaca dan dirancang sebagai kumpulan elemen elemen yang tidak diarahkan pada ekspresi dan makna yang formal, tetapi untuk membingkai kondisi strategis dan memungkinkan dari perasaan yang muncul, yang diwujudkan dalam kondisi tektonik dari sinematik dan arsitektural.

Pembahasan dari sinema untuk arsitektur dapat mempertemukan pemikiran kondisi tematik proyek arsitektur dengan diartikulasikan, diselidiki, diuraikan, dan dikerjakan secara konseptual, kontekstual, arsitektonis, dan teknis. Mencari potensi dan makna untuk membuka batas dan mengembangkan makna yang sudah ada lebih jauh. Dalam proses menggambar dari sinema untuk arsitektur, untuk mengembangkan kegunaannya untuk proses desain. Cakupannya terbatas pada tektonik, organisasi spasial, komposisi volumetric, intensitas cerita , pengalaman spasial, dan kondisi fenomenologis arsitektur, dengan memperhatikan cara film "dibuat" dan dibangun. Tektonik produksi, cara hal-hal disusun dan dirakit, cara kumpulan memberikan perwakilan dalam produksi lebih lanjut.

Untuk membahasnya dengan menguraikan aspek cerita, tempat dan setting, waktu, spasial, dan material yang kemudian direkonstruksi membentuk ruang berdasarkan observasi dari ruang sinematik yang ditayangkan. Sehingga kedepannya dapat mengembangkan manfaat yang didapatkan dari menonton film untuk proses desain arsitektur kedepannya.

\section{KAJIAN TEORI}

Sinema Dalam Arsitektur. Dalam buku Agencies of the Frame, menurut Michael Tawa, arsitektur dan sinema merupakan dua disiplin kreatif yang berbeda yang memiliki bahasa dan aturan masing-masing, akan tetapi pada di area yang saling tumpang tindih. Area 
tersebut merupakan kualitas, kondisi, dan teknik yang ditemukan dalam film dapat di digunakan untuk perancangan, strategi, praktek, dan representasi dalam arsitektur. Sinema dengan arsitektur memiliki persamaan sifat yang spasial dan konseptual. Dalam bukunya, menekankan pada penarikan paralel antara cara sinema mengkonstruksikan film dan cara arsitektur mengkonstruksikan ruang, daripada menyatakan identitas kedua seni secara tersirat. Fokus pada kesamaan yang signifikan, tumpang tindih, dan resonansi sebagai area penelitian. (Tawa, 2010)

Arsitektur memiliki kemampuan untuk sangat mengubah dan membantu narasi pada film. Dalam memahami tektonika dalam sinema dan arsitektur, perlu dipahami apa yang termasuk dalam memahami tektonika secara ruang yang berarti "memahami bagaimana semua elemen tunggal dari sebuah bangunan diintegrasikan ke dalam satu kesatuan ruang yang harmonis dan organik."(Bötticher, 1844).

Ruang dalam sinema adalah penciptaan dunia di dalam frame, kemudian memiliki kualitas spasial terkait seperti enclosure dan exposure, layering, simetri, skala, proporsi dan ritme. Ruang didefinisikan menjadi empat sub komponen ruang: deep, flat, limited, dan ambiguous. Keempat sub komponen tersebut ditentukan dari penggunaan perspektif, dimensi, tekstur, gerakan objek yang ditangkap di dalam frame.

Michael Tawa memahami proses menggambar dari sinema untuk mengembangkan kegunaannya bagi arsitektur dalam proses desain dengan pemahaman tektonik produksi, cara hal-hal disusun dan dirakit, cara kumpulan memberikan perwakilan dalam produksi lebih lanjut melalui lima pendekatan.

Pendekatan pertama berkaitan dengan tempat dan setting. Arsitektur bertempatkan dan disituasikan dengan kondisi tertentu. Dari hal itu, film frame menjadikannya sebuah setting dan tempat. Setting menyesuaikan dengan isi, berfungsi sebagai salah satu sumber ataupun support sesuai dengan konteks yang tersedia. Terdapat 3 tipe dasar kaitan setting dengan karya film yaitu, indifferent (ketidakpedulian), aesthetic (estetika), atau productive (produktif), ketiga hubungan tersebut diidentifikasikan tergantung hubungan tempat dan cerita.

Spaciality merupakan pendekatan kedua. Diidentifikasikan dari antara keempat subkomponen ruang sinema. Ruang pada sinema dibentuk dari pengaturan perluasan, perlapisan, proporsi, bentuk, dsb. Manipulasi ruang dibangun frame dengan geometric yang statis dan dinamis, dimensi, dan juga potensi. Film dan bangunan dapat membingkai apa yang dilihat, baik itu yang sudah ditentukan maupun sudah dirancang, diaplikasikan untuk kondisi narasi yang formal, kontekstual pada arsitektur

Dalam film, temporality merupakan kondisi terpenting yang harus dibangun. Dalam pendekatan waktu, arsitektur tidak bisa memanipulasi waktu seperti film. Tapi dapat mempelajari dari tempo dan ritme yang digunakan pada film. Bagi arsitektur, perlu dibuat mengkondisikan ambience seperti pergerakan orang, variasi iklim, ritme, dan kondisi elemen yang disampaikan oleh, suara, cahaya, udara, air, bumi, dsb.

Pendekatan keempat yaitu, materiality sinema memembahas maksud dan cara bagaimana dalam produksi film dalam material dan teknologi dalam menampilkan suara dan cahaya. Selaim membuat gambar menjadi terlihat dan narasi tersampaikan, cahaya menjadi pokok untuk membangun daya tarik dan tone. Sehingga, narasi dapat dikembangkan dan diatur untuk mencapai emosi yang ingin dicapai. Arsitektur berperan sebagai penerima, pengubah, atau mengirimkan cahaya yang dapat mengatur kualitas ruang,

Dan yang terakhir penggabungan (assemblage). Cara film dan bangunan dibuat, dirancang, dan dialami akan berbicara tentang tempat dan pembuatan letak; spatiality, organisasi dan komposisi geometris; temporality dan orientasi pada durasi dan waktu; materiality dan perspektif tentang cahaya, suara, tekstur dan getaran, material dan disposisi 
dan pengaturan teknologinya. Dalam konseptualisasi, eksistensi, dan pengalaman film dan bangunan, bidang-bidang ini berfungsi sebagai kumpulan dengan agensi tertentu.

\section{METODE PENELITIAN}

Penelitian ini adalah studi ruang sinematik dengan cara analisis kasus film Ave Maryam (2020) yang termasuk pada Kelompok Bidang Ilmu Sejarah, Teori, dan Falsafah Arsitektur (KBI STEFA) Universitas Katolik Parahyangan. Jenis penelitian adalah deskriptif kualitatif. Penelitian dilakukan dengan cara mengobservasi film Ave Maryam dengan mengamati unsur unsur yang ada pada film dan kemudian dikaji dari kelima pendekatan sinematik film dan Arsitektur dari film Ave Maryam (2020) yang mengambil tempat di Komplek Kesusteran St. Fransiskus, untuk menghasilkan kesimpulan.

\section{ANALISIS}

\subsection{DATA UMUM}

Komplek Kesusteran St. Fransiskus berlokasi di Jl. Ronggowarsito No.8, Tj. Mas, Kec. Semarang Utara, Kota Semarang, Provinsi Jawa Tengah. Dekat dengan Kawasan Kota Lama Semarang yang berjarak kurang lebih 1,6 km. Kesusteran ini merupakan bagian dari komplek Gereja dan Susteran Gedangan, yang terdiri dari Komplek Kesusteran, Gereja St. Yusuf Gedangan, Komplek Sekolah Marsurdirini, dan Sekolah Tinggi Pastoral Katekik. Pada tahun 1906 pertama kali dibangun menjadi rumah sakit, lalu berganti fungsi menjadi sebagai biara, panti asuhan yatim piatu, tempat perawatan kesehatan, dan juga sekolah pada tahun 1987.

Film Ave Maryam (2020) memiliki konsep yaitu cinta, yang merupakan bahasa yang universal sehingga dalam memvisualisasikannya pun diutamakan keindahan, kesederhanaan, dan realistis. Kota Semarang dipilih menjadi lokasi cerita karena menurut sutradara, Ertanto Robby Soediskam, Semarang memiliki arsitektur dan ornamen peninggalan lama yang dianggapnya memiliki kesan romantic. Komplek Kesusteran St. Fransiskus menjadi setting utama, namun tidak semua yang diceritakan bertempat di Kesusteran benar- benar berada di Komplek Kesusteran tersebut, untuk beberapa ruang diubah dengan alasan artistik.

\subsection{IDENTIFIKASI KUALITAS SINEMATIK BERDASARKAN FILM AVE MARYAM}

Untuk menganalisis kualitas sinematik Bioskop Metropole, sebelumnya dipilih beberapa ruang dalam film Ave Maryam berdasarkan intensitas cerita dalam teori pada buku Visual Story, sebagai berikut:

Tabel 1. Tabel Analisa Grafik Intensitas Cerita

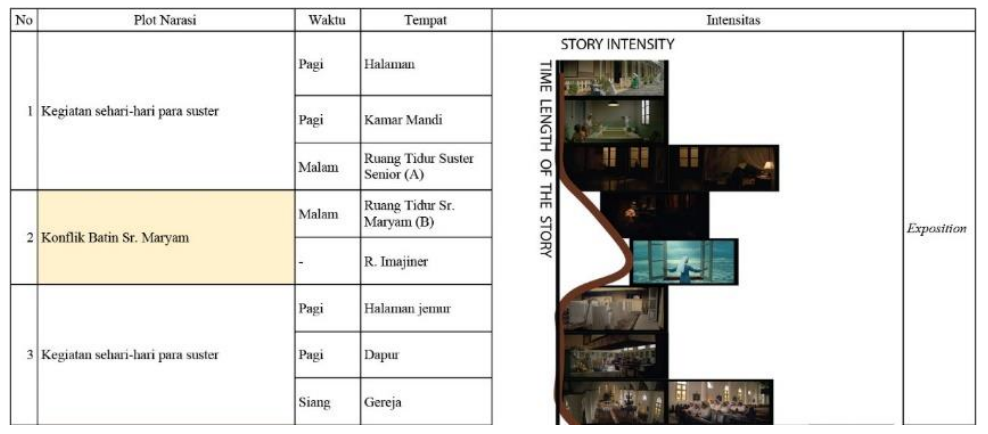



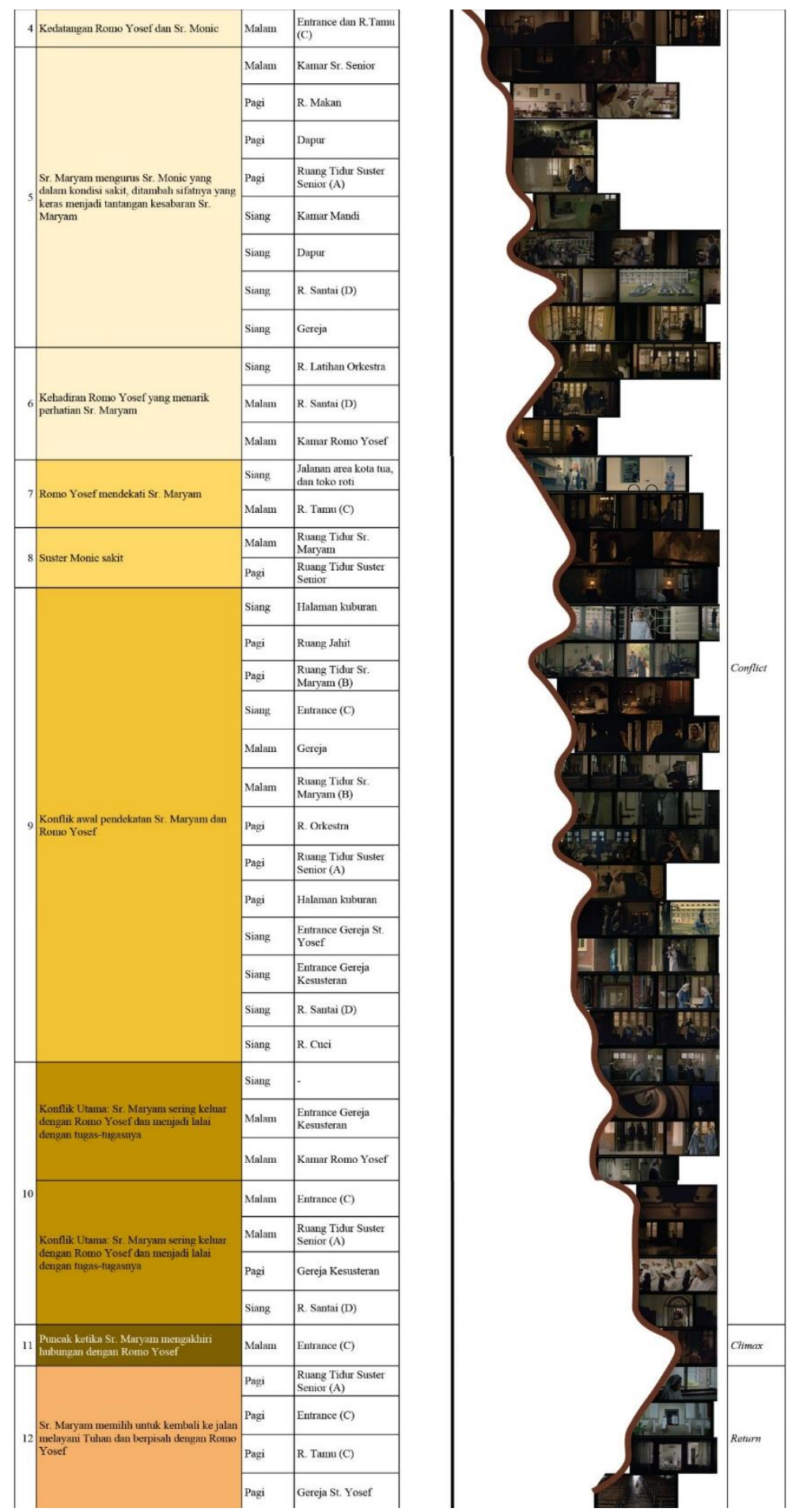

Dari tabel di atas warna menunjukan tingkat intensitas keseluruhan plot narasi dimana semakin gelap maka ceritanya semakin intens. Durasi awal merupakan exposition, yang merupakan pembukaan film berupa pengenalan awal cerita, menunjukan keseharian para suster di Kesusteran St. Fransiskus dan awal dari kegelisahan Sr. Maryam. Kemudian, kedatangan Romo Yosef dan Sr. Monic menjadi awal konflik dan memuncak pada klimaks dan kemudian turun dimana cerita tersebut kembali ke keadaan semula dengan kondisi yang berbeda. Setting tempat diuraikan tiap ruang yang ditempati dengan grafik yang menunjukan ketika adegan yang sedang intens pada tiap bagian plot nya yaitu ketika berada di R. Tidur 
Suster Senior, R. Tidur Sr. Maryam, R. Rekreasi, R. Tamu dan Entrance. Dan ruang yang tingkat intensitas cerita tertinggi ketika berada di Entrance pada malam hari.

Terbentuknya ruang sinematik pada film Ave Maryam dipengaruhi dari pendekatan tektonika yang paralel antara sinema dan arsitektur, yaitu setting dan tempat, temporality, spatiality, dan materiality. Diawali dari ruang yang dipengaruhi dari identitas tempat, Komplek Kesusteran St. Fransiskus, menjadi tempat utama yang ditempati (taking place) oleh peristiwa yang terjadi dalam film Ave Maryam (2020). Dalam film ini, menunjukan Komplek Kesusteran St. Fransiskus sebagai sarana untuk suster tinggal dan memperlihatkan ruang sebagaimana digunakan untuk aktivitas keseharian para suster. Terlihat perbedaannya dengan film Indonesia lainnya, Film Ave Maryam menggambarkan emosional yang disuguhkan secara meruang, memberikan penontonnya alur yang tenang dalam keadaan keingintahuan dan hasrat yang kuat.

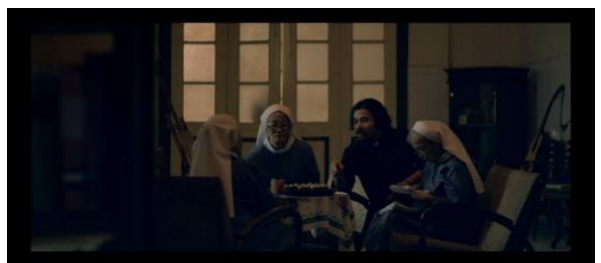

Gambar 1. Film still pada setting Ruang Rekreasi (sumber: Netflix)

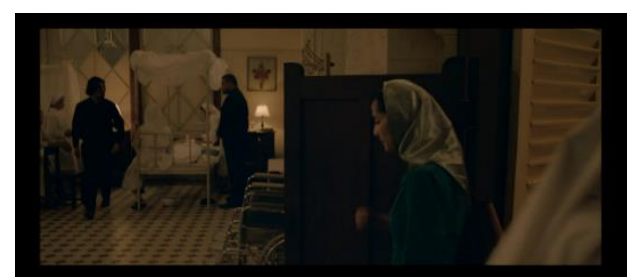

Gambar 2. Film still pada setting Ruang Tidur Suster Senior (sumber: Netflix)

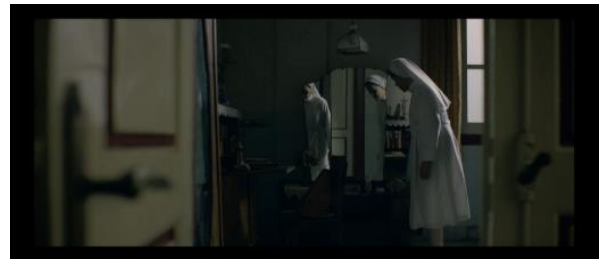

Gambar 3. Film still pada setting Ruang Tidur Sr. Maryam (sumber: Netflix)

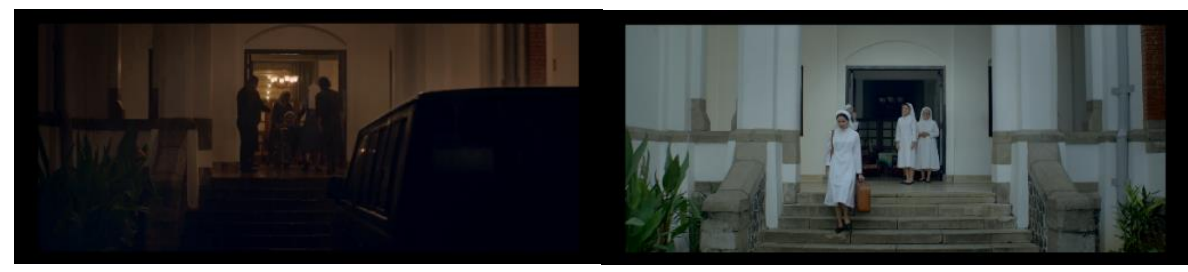

Gambar 4. Film still pada setting Entrance (sumber: Netflix)

Ruang - ruang yang ditampilkan (gambar 1-4) memiliki hubungan aesthetic, berarti pengaturannya bagaimana ruang terbentuk haruslah sesuai dengan fungsi ruang tersebut dan berinteraksi dengan objek dan elemen yang ada dari setting yang sudah dibuat, atau yang sudah ada. R. Rekreasi yang aslinya merupakan sebuah ruang tamu yang jarang sekali digunakan, dibuat sebagai ruang rekreasi, digambarkan pada film menampung kegiatan yang dilakukan ketika sedang mencari hiburan seperti membaca, melukis, dan bermain papan permainan di tengah ruangan, atau bisa juga berdansa, yang membuat perabotan kursi-kursi dipinggirkan untuk membuat ruang lebih leluasa dalam bergerak.

Pada R. Tidur Sr. Maryam, aslinya merupakan ruang kosong di Komplek Kesusteran St. Fransiskus, dibuat sedemikian rupa mengikuti sebagaimana kamar pada umumnya. Ruang ini memiliki peran dalam narasi, merepresentasikan kamar pribadi sehingga terasa kesendirian yang dialami Sr. Maryam, dan ketika orang lain masuk, seperti pada adegan 
dimana Sr. Monic masuk ke dalam kamar tersebut, ruang tersebut menjadi terasa terganggu keprivasian-nya.

Keempat setting yang bukan merupakan ruang fungsi aslinya menjadikan keempat ruang tersebut menjadi ruang fiksi, akan tetapi masih dapat menggambarkan kenyataan dari fungsi ruang yang semestinya, dengan perencanaan pada tahap pra-produksi. Walaupun berbeda bangunan, penonton tetap melihat ruang tersebut seperti masih di dalam satu area.

Dalam waktu membahas "the particular time" ataupun durasi. Pergerakan realitas berdasarkan fakta secara spesifik dalam waktu dan keunikan yang melekat pada suatu kejadian, benda, dan orang - orang yang berinteraksi dalam suatu adegan dan adegan lainnya. Seperti ketika berada di Entrance dan Ruang Tamu di tabel berikut,

Tabel 2 Tabel identifikasi Temporality

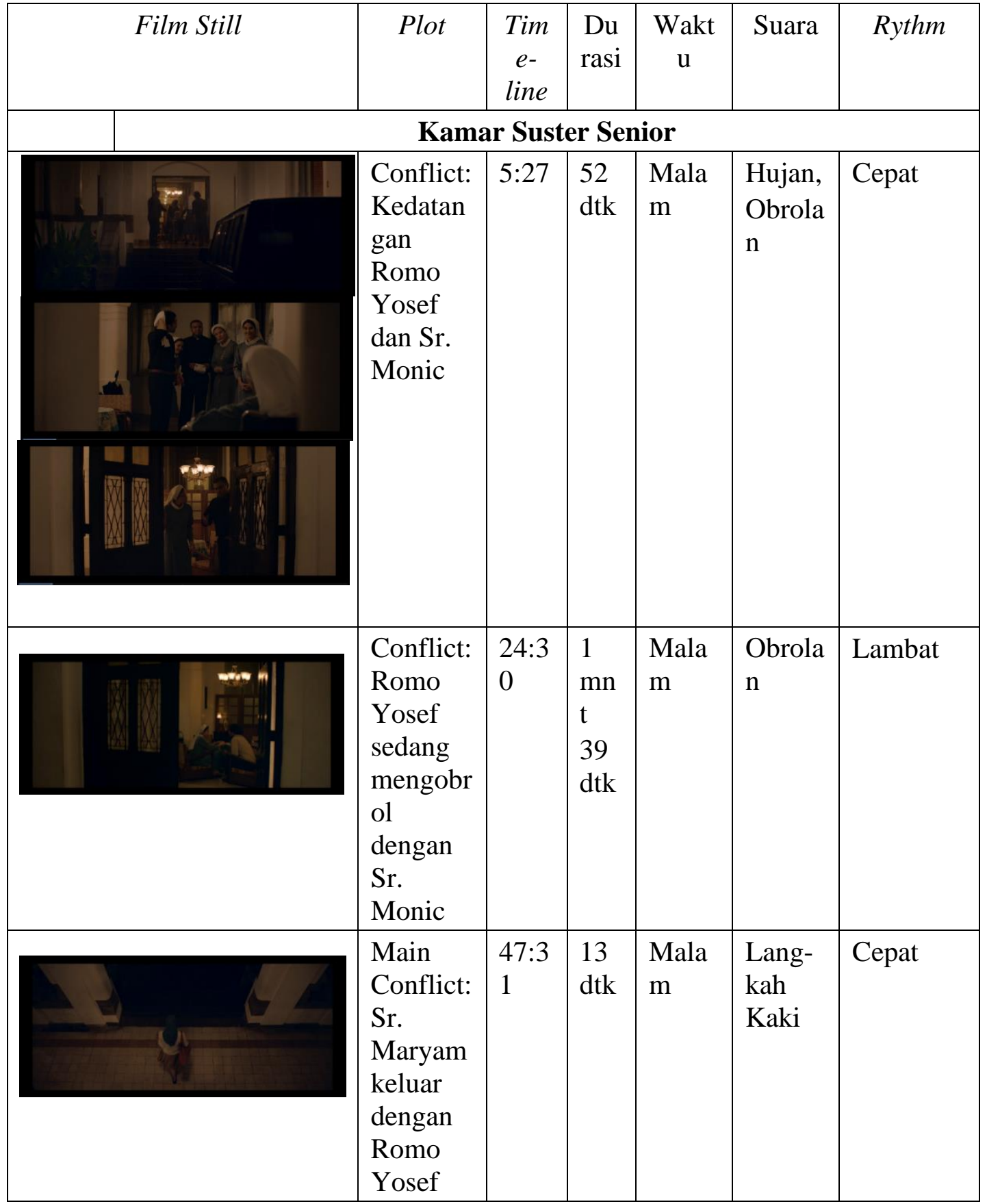




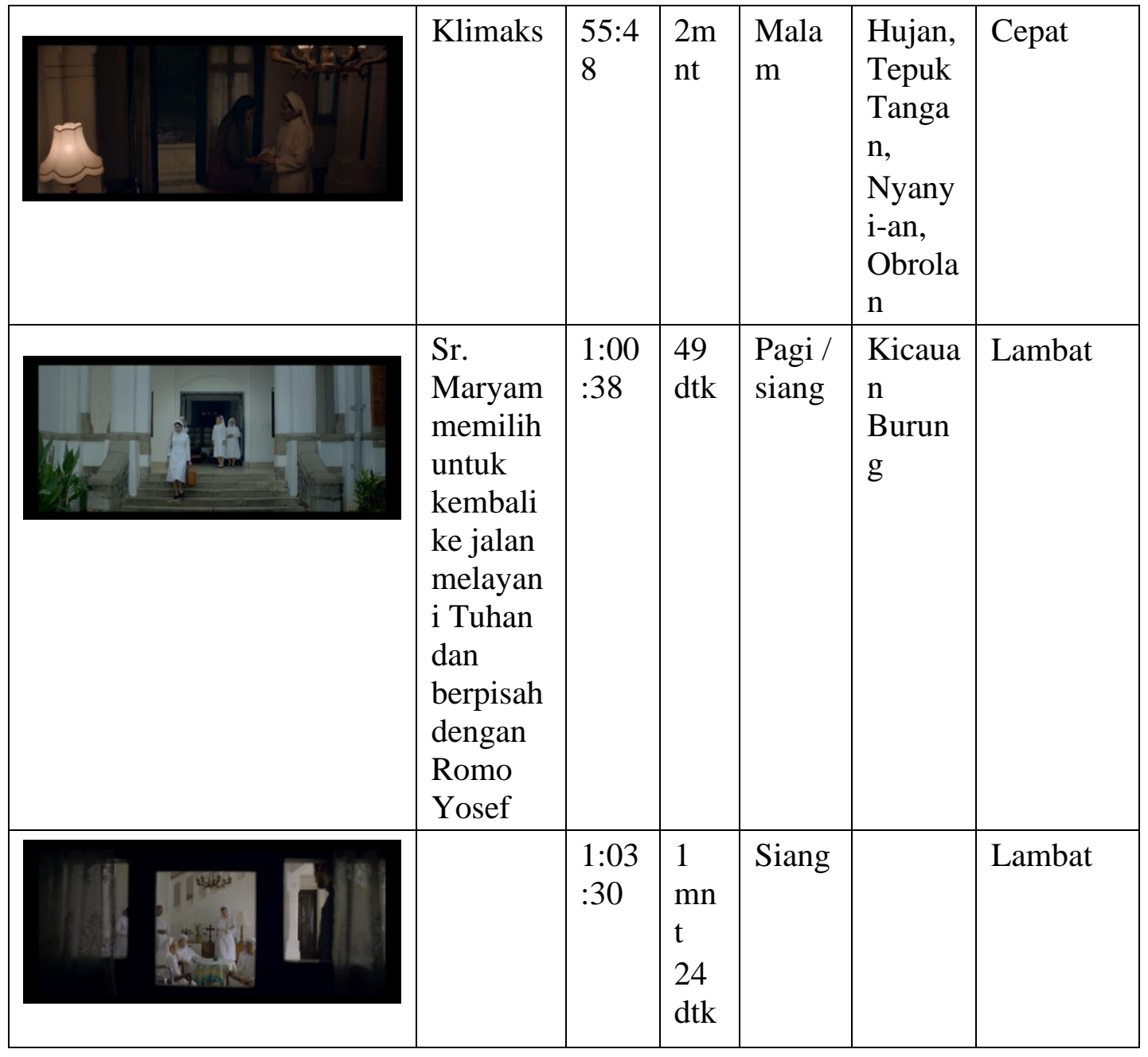

Dalam plot gambar yang dalam satu tabel terdapat pengambilan berbagai angle merupakan bagian dari montase. Dalam satu montase pengalaman ditunjukan dari tempo. Sedangkan pada plot lainnya ditunjukan dalam satu adegan yang kamera mengambil gambar perjalanan waktu menangkap momen cerita dengan arah pandang penonton mengikuti pergerakan aktor tanpa interupsi. Tempo ditunjukan dari pergerakan karakter.

Pada ruang Entrance (Tabel 2), memperlihatkan keadaan "entrancement" yang melibatkan dua fase ketika masuk konflik dan return. Proyeksi 2 adegan secara paralel dalam satu angle menunjukan hal yang berlawanan - masuk-keluar, pertemuan-perpisahan, malamsiang, serta awal-akhir. Kedua gambar memberikan jejak dari bagian lintasan yang sulit.

Waktu dalam film Ave Maryam berjalan dengan normal sesuai dengan kenyataan, sehingga yang membentuk ruang sinematik dari segi temporal ialah tempo dan suasana. Adanya tempo dan suasana muncul dari pergerakan dan suara di dalam ruang seperti ketika ruang diperluas dengan musik yang dimainkan menambah tempo di dalam ruangan dan juga mengubah suasana menjadi lebih aktif. Atau dapat juga muncul dari pencahayaan dan suara yang ada pada titik klimaks, ruang yang hening dan gelap ketika pintu dibuka langsung masuk suara hujan yang deras dan nyanyian dan tepukan bersamaan dengan lampu yang dinyalakan mengejutkan menambah tempo dan menaikan intensitas cerita hingga semuanya bubar dan menyisakan suara hujan dan tangisan menjadi titik klimaks.

Ruang-ruang yang tergambarkan pada film dengan memori kisah cinta yang diceritakan. Dalam membahas soal cinta, membicarakan memori yang berjalan apa adanya sepanjang waktu yang ditampilkan. Arsitektur dan kota memberikan tahap yang penting 
dalam mengoleksi memori. Pada film Ave Maryam pun dapat memberikan pengalaman yang mengingatkan dan membuka secara aktif memori yang kolektif maupun personal.

Dalam "moment of vision of genuine action" ( memecahkan perjalanannya waktu. Waktu "present" saat kita menonton merupakan "past" dari kisahnya Sr. Maryam ketika berada di Kesusteran. Waktu dalam "present" dialami sebagai perjalanan memori kisah suster maryam, dan pengiringan tempo didalamnya diatur dari pergerakan di dalam ruang.

Walaupun frame membatasi penglihatan karena secara umum film ini menggunakan frame dengan rasio 2.40:1, hampir 21/2 kali lebih lebar dibandingkan dengan tingginya. Biasa disebut Cinemascope, sistemnya menggunakan lensa anamorphic untuk membuat rasio menjadi lebar. Spasial pada film Ave Maryam dibentuk dari pengaturan perluasan, perlapisan, proporsi, bentuk dari tiap elemen yang mempengaruhi kedalaman ruang. Berikut salah satu contoh tabel penggambaran ulang tiap ruang yang terpilih untuk menentukan kedalaman ruang:

Tabel 3 Tabel ilustrasi Spatiality

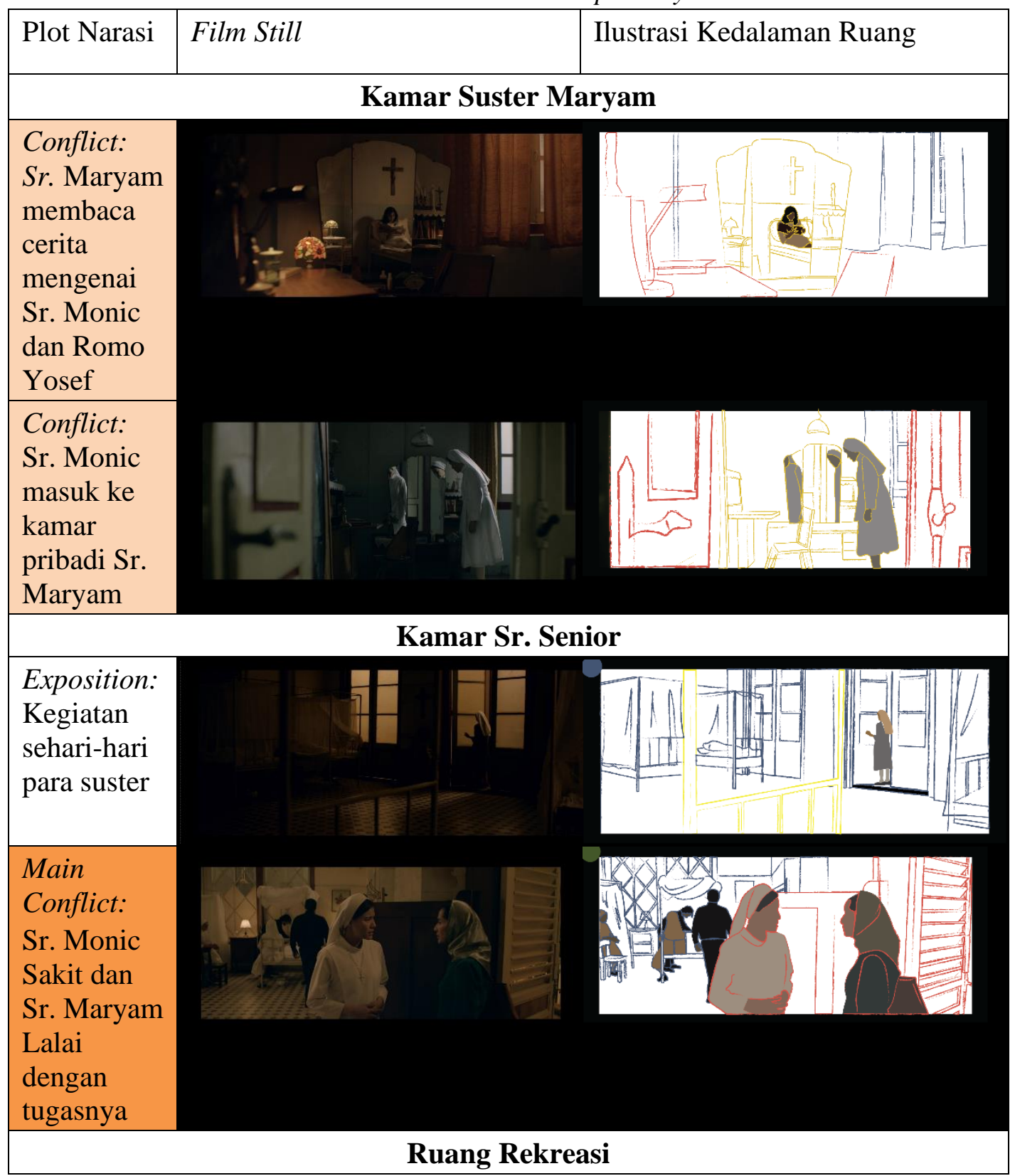




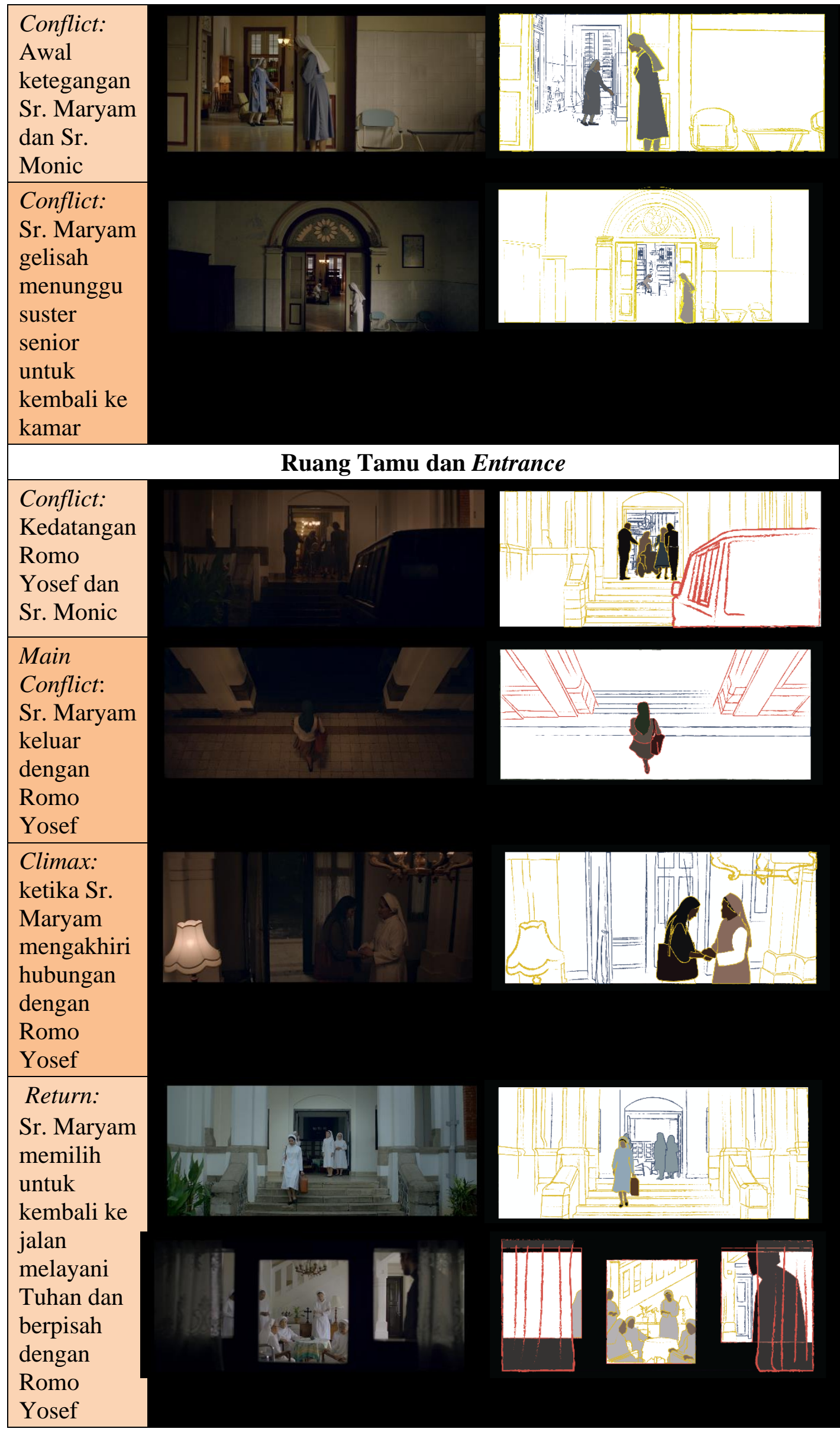


Keseluruhan pengambilan gambar digunakan dengan wide frame. Menurut Ertanto Robby, secara sinematik dengan wide sudah terwakilkan ruang maupun dunia yang luas di luar hati Maryam. Ruang dirender secara frontal dalam perspektif dengan satu titik hilang. Representasi spasial membantu meratakan gambar menjadi gambar 2D. Penggunaan perspektif satu titik hilang juga menciptakan penekanan dari efek dinamis antara karakter sebagai pengguna ruang dan elemen arsitektur yang menonjol. Kebanyakan menggunakan pergerakan kamera yang still ketika membicarakan soal cinta berarti membicarakan apa yang ada di dalam diri kita bukan euphoria, sehingga pengambilan gambar ruang dan biarkan karakternya bergerak bebas.

Pintu dan jendela berfungsi sebagai frame dalam frame film. Ataupun elemen lain seperti kelambu dan partisi kayu yang memberikan proporsi mengiris ruang kedalam pemikiran yang melihat, dalam hal ini berarti penglihatan penontonnya. Frame in frame membuat area di dalam nya menjadi fokus utama. Ruang pun menjadi masuk ke dalam subkomponen limited space karena ada penegasan antara foreground, midground, dan background yang jelas. Pintu sebagai perpindahan antar ruang memungkinkan subjek keluarmasuk dari frame, ketika hal tersebut terjadi fokus pun menjadi kabur. Sedangkan, untuk jendela tidak adanya perpindahan ke dalam-keluar, sehingga jendela disini hanyalah sebagai frame untuk melihat kedalam frame tersebut. Keluar dari frame disini berarti keluar dari pengelihatan.

Ada pengecualian pada beberapa adegan yang menggunakan deep space dan ambiguous space. Deep space seperti pada ruang kamar suster senior di gambar baris pertama memperlihatkan kedalaman dan perspektif yang jelas tanpa ada bidang frontal yang membagi frame. Sedangkan penggunaan ambiguous space ketika menggunakan pantulan cermin untuk menggambarkan ruang sehingga memberikan keambiguan pada dimensi ruang yang ditampilkan. Dan juga ketika pengambilan angle dari atas bukan dari mata manusia sehingga gambar menjadi terdisorientasi.

Kemudian, berikut adalah penjabaran pembahasan Materiality di setiap adegan pada keempat ruangan yang dipilih:

Tabel 4 Materiality pada tiap ruangan

\begin{tabular}{|l|l|l|l|}
\hline Scene dan Color Scheme & Tone & $\begin{array}{l}\text { Sumber } \\
\text { Cahaya }\end{array}$ & Keterangan \\
\hline \multicolumn{3}{|c|}{ Kamar Suster Maryam } \\
\hline & $\begin{array}{l}\text { Warm } \\
\text { Dark } \\
\text { Tone }\end{array}$ & $\begin{array}{l}\text { Lampu } \\
\text { meja - } \\
\text { Cahaya } \\
\text { dari luar } \\
\text { tidak } \\
\text { diketahui) }\end{array}$ & $\begin{array}{l}\text { Cahaya dari kedua } \\
\text { lampu meja berwarna } \\
\text { kekuningan, mengenai } \\
\text { permukaan meja dengan } \\
\text { veneer kayu, redup pada } \\
\text { area dinding, dan } \\
\text { pantulan cermin. Dari } \\
\text { luar ruangan terdapat } \\
\text { cahaya yang tertutup } \\
\text { tirai berwarna jingga. } \\
\text { Warna yang } \\
\text { mendominasi merupakan } \\
\text { warna dengan toe hangat }\end{array}$ \\
\hline
\end{tabular}




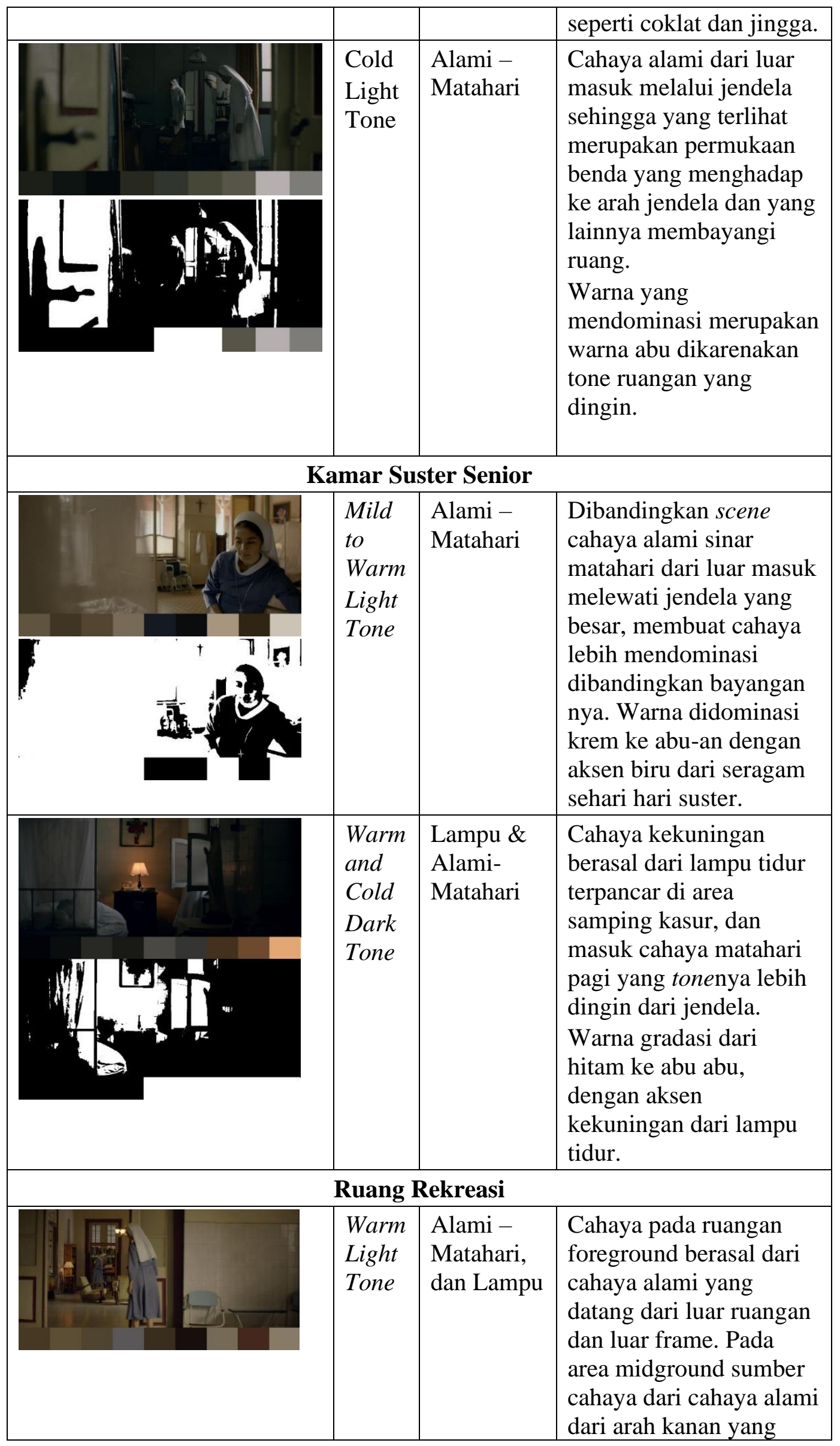




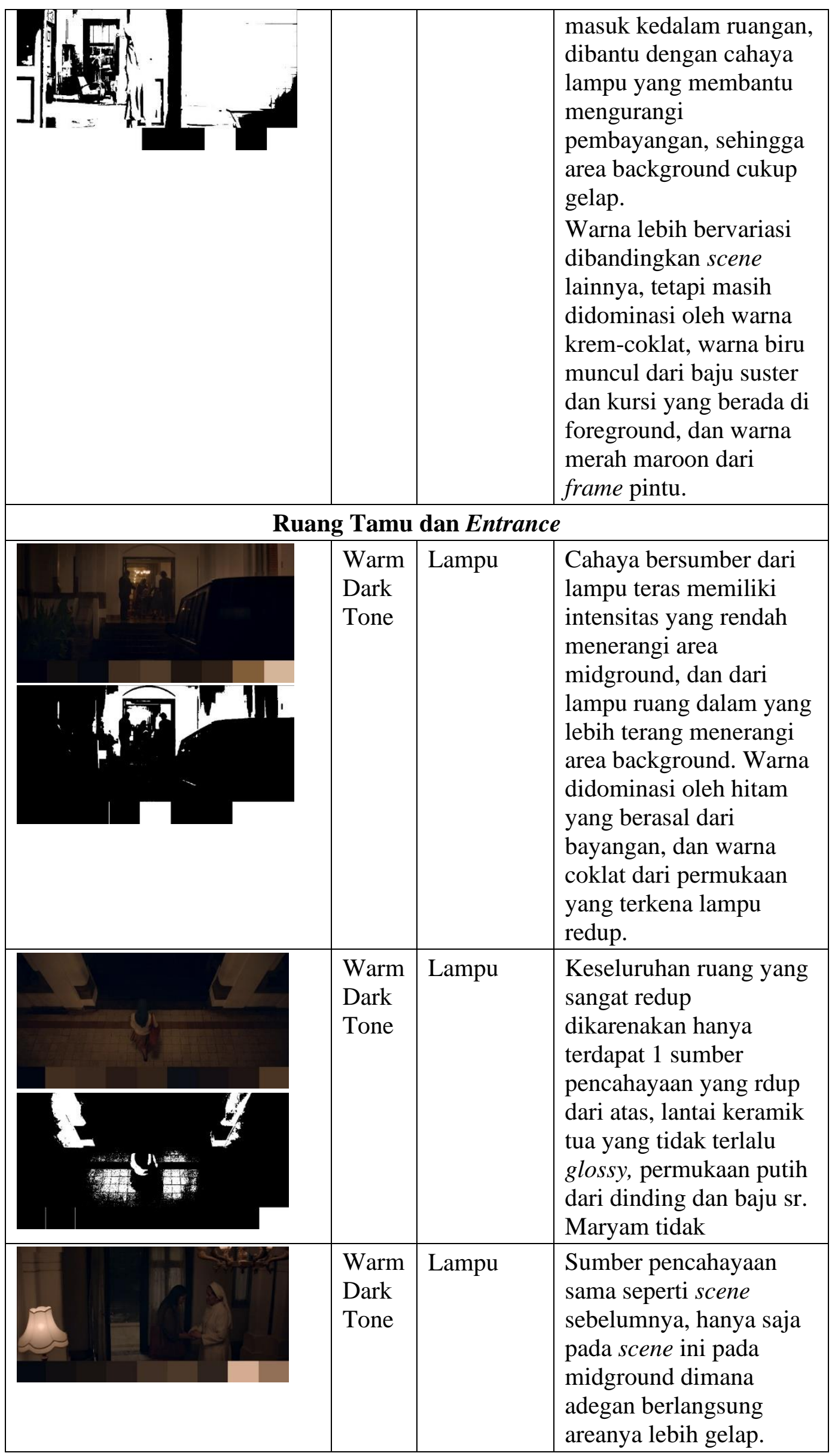




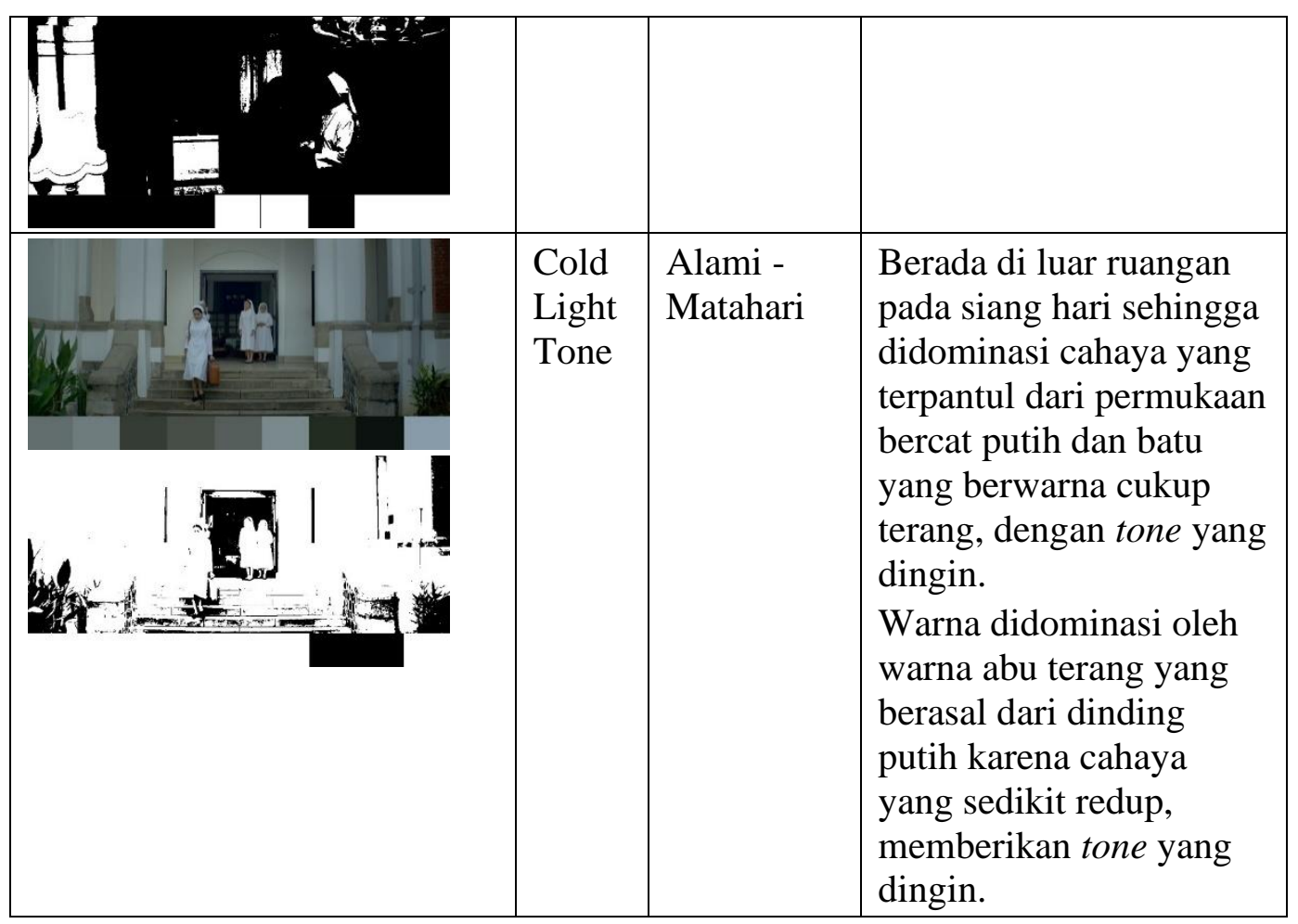

Dari tabel diatas dapat dilihat bahwa warna dari material dari elemen-elemen dan objek-objek pada ruang menunjukan dominasi bagi cahaya dan waktu yang ditampilkan dalam pengambilan gambar. Jenis pencahayaan buatan dari lampu yang berada di dalam maupun luar ruangan pada malam hari dan alami dari sinar matahari dari luar ruangan pada pagi atau siang hari, mempengaruhi tone yang terlihat oleh penonton. Pencahayaan yang $90 \%$ secara natural dan minimnya rekayasa sehingga sama seperti halnya dalam perencanaan bangunan, dalam film pun diperlukan perencanaan perletakan, dan jadwal pengambilan gambar yang sesuai dengan apa yang ingin ditampilkan.

Seperti pada pembahasan sebelumnya, disini juga elemen pintu dan jendela memiliki peran penting. Jendela dan pintu untuk melihat kedalam atau keluar, maupun sebagai pembuka bagi cahaya untuk masuk, sama pentingnya sebagai fungsi untuk orang lewat.

Warna yang ditonjolkan dalam film ini ialah warna sepia. Sepia merupakan warna coklat yang agak gelap, seperti warna-warna pada foto jaman dahulu. Warna ini pada umumnya memberikan tone yang hangat dan memberikan rasa sentimental dan kerinduan terhadap masa lampau. Warna sepia juga sangat cocok dengan konsep cinta dan juga ketenangan dan kelembutan yang ditonjolkan dari karakter cerita dan juga karakter bangunan. Warna tersebut keluar dari finishing material elemen elemen pembentuk ruang yang berada di dalam frame, dibantu juga dengan pencahayaan yang mengenai elemen tersebut. Bangunan lama menjadi peran penting dalam menggambarkan ruang dengan menciptakan atmosfer yang romantis.

\subsection{REKONSTRUKSI RUANG SINEMATIK KOMPLEK KESUSTERAN ST. FRANSISKUS}

Frame yang terbatas memiliki jejak elemen diluar yang terbayangi dari imajinasi yang muncul dari pengalaman. Kombinasi dari komposisi tempat, ruang, waktu, materiality, dan teknologi produksi, mengubah fokus dari penerimaan dan peniruan yang pasif menjadi aktif. Mengatur pada hal untuk melakukan sesuatu atau membuat sesuatu terjadi dari apa yang diadaptasi oleh film. Pembentuk Ruang dari Frame (Agencies of the Frame) dari pendekatan 
sinema dalam menggambar ruang yang ada di Komplek Kesusteran St. Fransiskus dari keempat ruang, sebagai berikut:

Tabel 5 Tabel ilustrasi pembentukan ruang

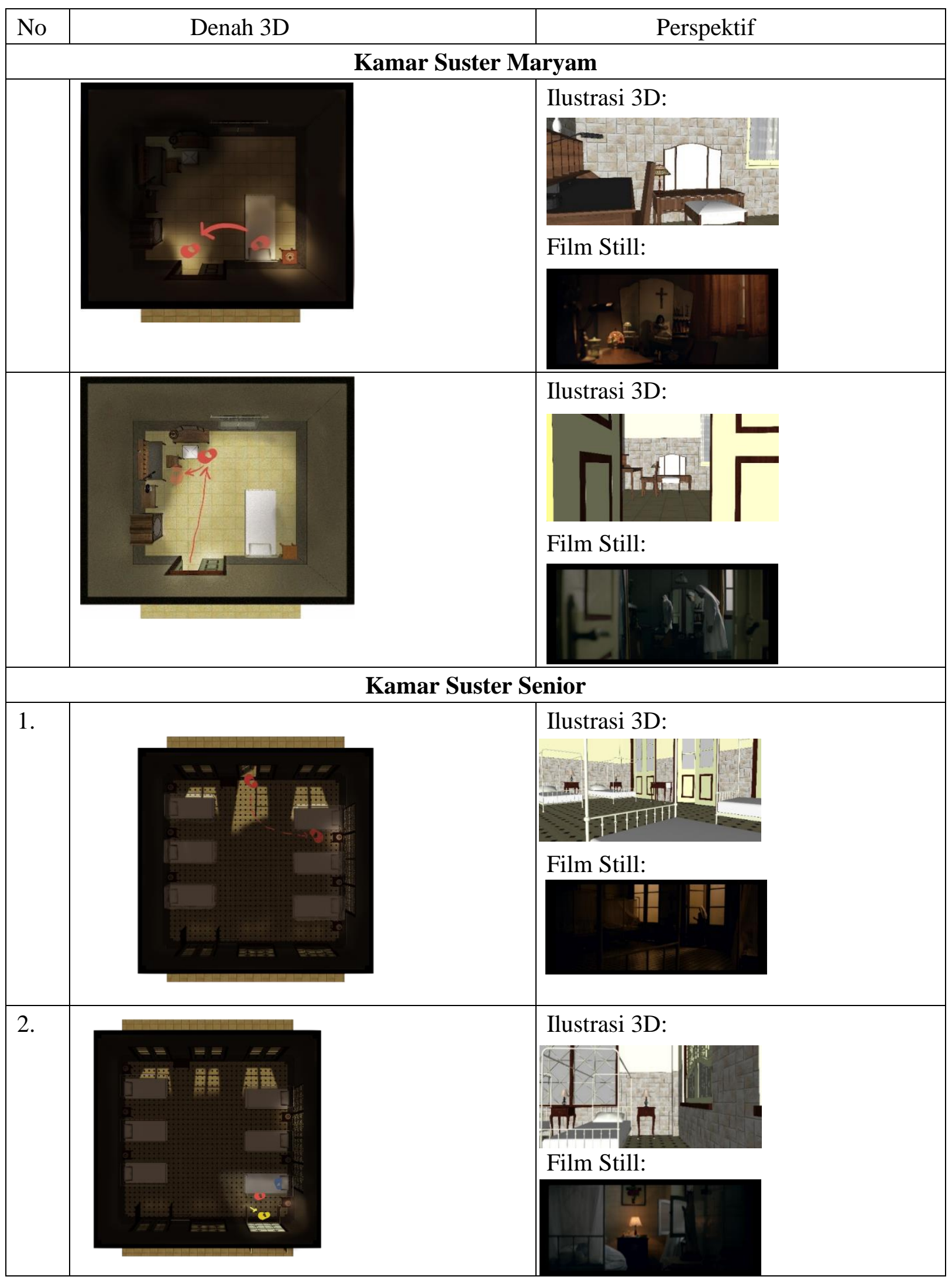




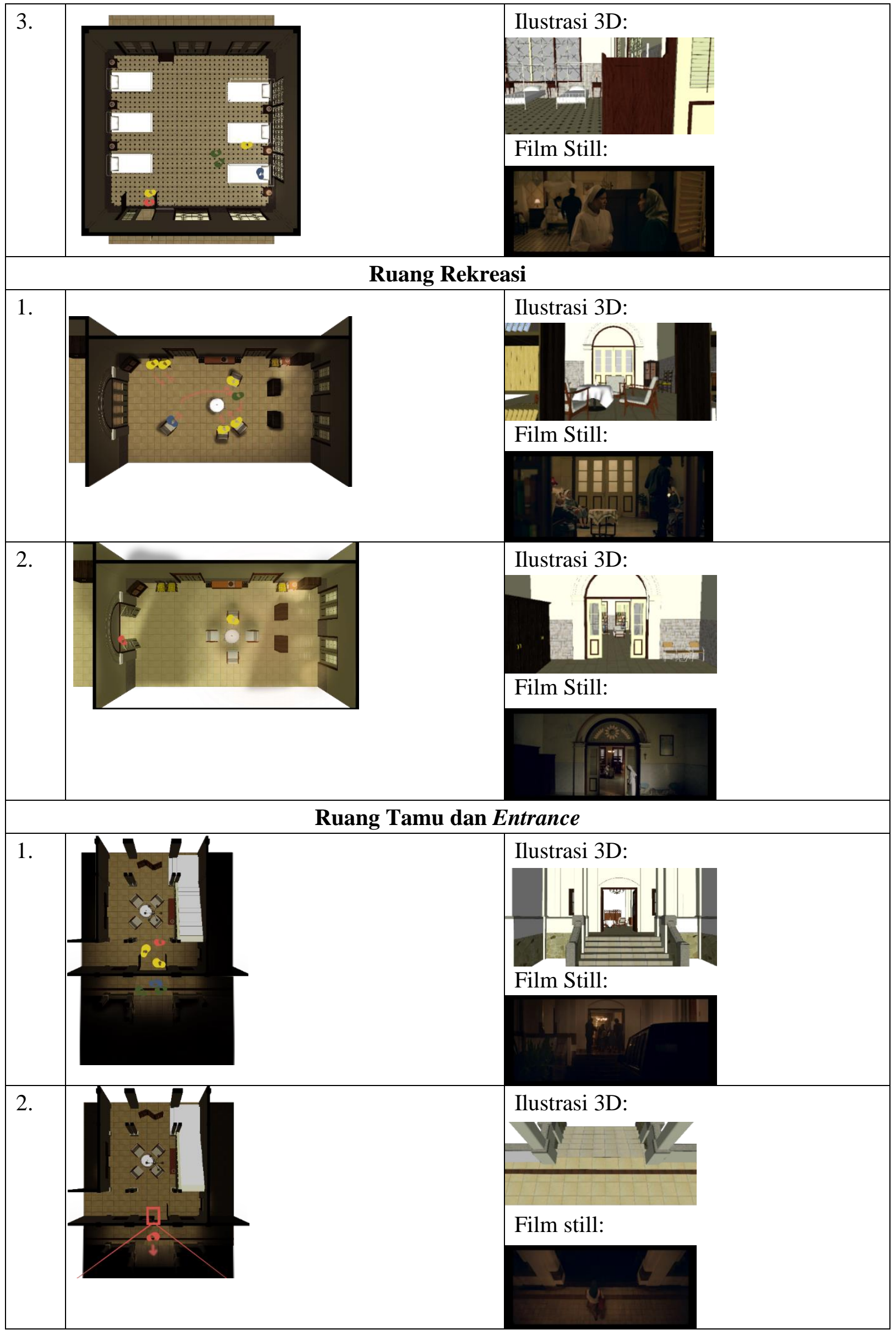




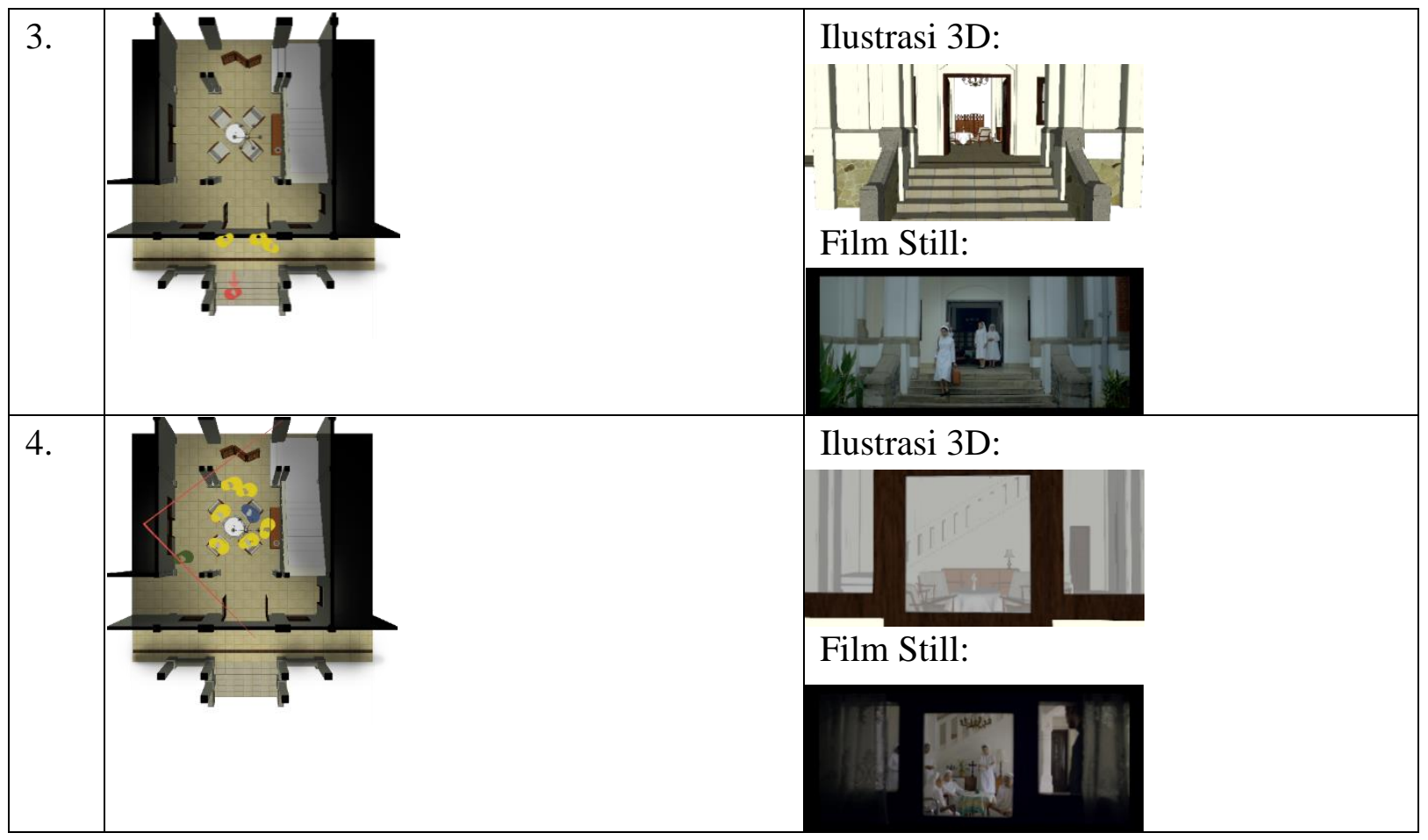

Penggambaran denah ruang, lalu perletakan tiap objek, kamera, dan pemeran yang sudah dirancang sebelumnya oleh pembuat film, dibuat untuk memahami perletakan tiap elemen pembentuk ruang dan pembingkaian ruang tersebut dalam setiap adegan terpilih dalam film Ave Maryam

Ruang pribadi Sr. Maryam bersifat privat memiliki volume ruang yang kecil dengan bukaan yang minim hanya memiliki satu jendela. Pintu disini sebagai mediator antara dua dunia, yaitu dunia publik dan intimasi dari sebuah kamar pribadi. Sehingga, ketika ada orang luar masuk akan merusak sifat dari keprivasian ruang tersebut. Sedangkan Kamar Sr. Senior yang lebih luas dan memiliki kapasitas pengguna yang lebih banyak. Kamar ini pun menjadi lebih publik tercermin dari banyak nya bukaan pada pada ketiga sisi dinding, dengan pintu dan jendela yang skalanya lebih besar sehingga proporsi secara horizontal bukaan pun lebih besar dibandingkan dinding yang menutup ruangan. Dari aktivitas di dalamnya pun dapat terlihat dimana orang, selain yang tidur di keenam kasur dalam ruangan, bisa keluar masuk ruang tersebut.

Pada ruang rekreasi tiap adegan memiliki, bidang bidang-bidang vertikal yang paralel yang membentuk multiple layer. Multilayer tersebut merupakan foreground, middleground, dan background. Sehingga tegak lurus dengan kedalaman ruang lebih terasa. 


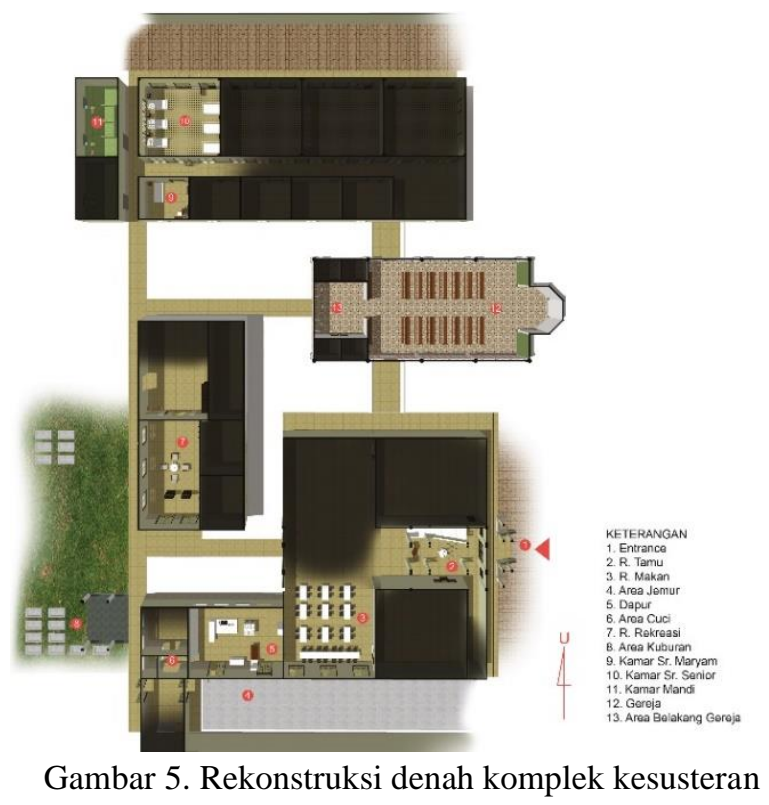

Dituliskan pada film bertempat di Kesusteran Mitra Sepuh sebagai objek arsitektur fiksi yang menginterpretasikan objek arsitektur Komplek Kesusteran St. Fransiskus. Ruang dibentuk oleh perjalanan karakter. Ruang sinematik terbentuk dari pengaturan ruang yang digubah mengacu pada ruang geomterik yang menghasilkan keindahan dan pengalaman atmosfer dan emosi seperti tegang, intim, ceria, sedih dan sebagainya dari keempat pendekatan ruang sinematik didukung pembayangan bentuk ruang dari luar frame pada film, dengan adanya persepsi untuk membentuk ruang baru yang linear dari potongan-potongan sekuens, persepsi privat dan publik ruangan yang tercermin dalam cerita, volume ruang, serta skala dan proporsi antara bukaan dan dinding, dan sumber pencahayaan, baik itu dari lampu maupun cahaya alami yang masuk melalui bukaan, pada Komplek Suster-suster St. Fransiskus.

\section{KESIMPULAN}

Melalui pendekatan yang digunakan, dapat dikenali keseluruhan strategi dalam membentuk ruang sinematik dan dicapai dengan pendekatan yang berbeda. Dari menggambar ulang dari film dapat membantu untuk memberi pengalaman dan studi ruang arsitektur dengan kualitas sinematik yang menambah nilai keindahan baik secara visual maupun audial pada ruang.

Film dan arsitektur dihubungkan menjadi temuan kontemporer, seiring dengan perlahan meningkatnya kualitas perfilman Indonesia, menarik untuk dikaji dari film dan arsitektur yang ada di Indonesia. Dengan ini diharapkan nilai pengalaman ruang dapat dipelajari lebih lanjut lagi diluar fungsi formal dalam arsitektur mencapai tingkat emosi tertentu dari apa yang didapatkan saat membahas film dan arsitektur lainnya.

\section{DAFTAR PUSTAKA}

Architecture and the Moving Image: Cinematic strategies in design and representation. (1994). Master Thesis of Architecture of The Auckland University, 128.

Block, B. (2008). The Visual Story. Oxford: Elsevier. 
Karnak, I. (2018). Architecture of The Single Room Movie: Tectonic, Scenographic, and Hybrid Space. A Thesis of Master of Architecture, 164.

Koeck, R. (2013). Cinescapes: Cinematic Spaces in Architecture and Cinema. New York: Routledge.

Pallasmaa, J. (1994). Space and Image in Andrei Tarkovsky's Nostalgia: Notes on a Phenomenology of Architecture. In A. Pérez-Góme, \& S. P., Chora1: Intervals in the Philosophy of Architecture (pp. 143-166). Montreal: McGill-Queen's University Press.

Penz, F. (2018). Cinematic Aided Design. New York: Routledge.

Schwartz, C. (2007). Introducing Architectural Tectonic: Exploring The Intersection of Design Construction. New York: Routledge.

Tawa, M. (2010). Agencies of The Frame: Tectonic Strategies in Cinema and Architecture. New Castle: Cambridge Scholars Publishing.

Vidler, A. (1993). The Explosion of Space: Architecture and the Filmic Imaginary. The MIT Press, 44-59. 